\title{
Ganho de Peso, Eficiência Alimentar e Características da Carcaça de Novilhos de Origem Leiteira ${ }^{1}$
}

\section{Evandro de Oliveira Rocha ${ }^{2}$, Carlos Augusto de Alencar Fontes ${ }^{3}$, Mário Fonseca Paulino4, Márcio Machado Ladeira ${ }^{5}$}

\begin{abstract}
RESUMO - O objetivo deste trabalho foi avaliar o ganho de peso, a eficiência alimentar e as características da carcaça de novilhos de origem leiteira. Dezesseis novilhos de origem leiteira, com idade e peso vivo iniciais médios de 20 meses e $202,0 \mathrm{~kg}$, foram usados. Os animais foram divididos em quatro grupos: um grupo de animais foi abatido no início do experimento (AI) e três receberam alimentação ad libitum (AL-1, AL-2 e AL-3), sendo abatidos ao atingirem os pesos vivos individuais de 250,0; 300,0; e 350,0 kg, respectivamente. A ração continha proporção volumoso:concentrado de 1:1 na matéria seca, com 12,48\% de proteína bruta. Consumo de matéria seca por kg de ganho de peso vivo aumentou à medida que o peso vivo se elevou, de 250,0 para 350,0 kg. Não houve diferença no ganho de peso vivo entre os grupos AL-1, AL-2 e AL-3 (respectivamente, 1,26; 1,14; e 1,01 kg/dia). Não houve diferença também entre os três grupos, quanto às proporções dos tecidos muscular e adiposo e ossos na carcaça. Houve tendência de queda da porcentagem de ossos, com o aumento do peso do animal. Diferenças não foram observadas entre os grupos de rendimentos de carcaça e dos seus cortes primários. Equações lineares que permitiram boas estimativas do peso corporal vazio, em função do peso vivo e do peso da carcaça, foram obtidas.
\end{abstract}

Palavras-chave: característica de carcaça, ganho de peso, equação de predição, Holandês, novilho

\section{Weight Gain, Feed Efficiency and Carcass Characteristics of Dairy Steers}

\begin{abstract}
The objective of this work was to evaluate the weight gain, feed efficiency and carcass characteristics of dairy steers. Sixteen Holstein dairy steers with initial average age and weight of 20 months and $202,0 \mathrm{~kg}$ were used. The animals were divided into four groups. One group of animals was slaughtered at the beginning of the trial (AI) and three groups were ad libitum fed (AL-1, AL2 and AL-3) and they were slaughtered when the individual weights of 250.0,300.0 and $350.0 \mathrm{~kg}$ were reached, respectively. The diet contained 1:1 forage to concentrate ratio on dry matter basis with $12.48 \%$ of crude protein. Feed intake per kg of live weight gain increased as live weight increased, from 250.0 to $350.0 \mathrm{~kg}$. There were no differences in live weight gain among the three groups AL-1, AL-2 e AL-3 (respectively, 1.26, 1.14 , and $1.01 \mathrm{~kg}$ /day). There were also no differences among the three groups regarding to the proportion of muscle and fat tissues, and bones in the carcass. There was a tendency of decrease in the percentage of bones, as animal live weight increased. No differences were observed among the groups for carcass dressing and their primal cuts yield. Linear regression equations that allowed good estimates of empty body weight, in function of the live weight and of the carcass weight and in function of empty body weight, were obtained.
\end{abstract}

Key Words: carcass characteristic, weight gain, prediction equation, Holstein, steer

\section{Introdução}

O aproveitamento racional, para corte, dos bezerros originários de propriedades produtoras de leite requer melhor avaliação do seu potencial de crescimento e das características da carcaça, tendo em vista que as restrições alimentares normalmente impostas aos animais na fase de cria podem ter reflexo sobre o seu desempenho posterior, como animais de abate.

Os bezerros machos com altas proporções de raças leiteiras, mesmo de grande porte, como a Holandesa e Suíça Parda, são normalmente sacrifi- cados, logo após o nascimento, pois, apesar de terem bom potencial para ganho de peso, não conseguem se adaptar às condições de meio predominantes nas criações extensivas, conforme salientam ALLEONI et al. (1981) e LUCCI (1989).

BIONDI et al. (1984) comentam que o não aproveitamento em grande escala da potencialidade dos machos originários de rebanhos leiteiros, como produtores de carne de alta qualidade em sistemas a pasto ou confinados, contribui para o baixo índice de desfrute do rebanho nacional.

O potencial para corte, de bezerros de raças

\footnotetext{
${ }_{1}^{1}$ Parte da Tese de Doutorado do primeiro autor apresentada à UFV, parcialmente financiada pelo CNPq.

2 Doutor em Zootecnia, DZO/UFV, Viçosa, MG.

${ }^{3}$ Pesquisador Titular do LZNA, CCTA, UENF, Campos dos Goytacazes, RJ.

${ }^{4}$ Professor do Departamento de Zootecnia, DZO/UFV, Viçosa, MG.

${ }^{5}$ Estudante de Doutorado/UFMG.
} 
leiteiras de grande porte, especialmente o Holandês e seus mestiços, tem sido avaliado em inúmeras pesquisas no Brasil e exterior. VELLOSO et al. (1975), trabalhando com bovinos mestiços Holandês em regime de confinamento por período de 112 dias, observaram ganhos médios diários e rendimento de carcaças de $1,128 \mathrm{~kg}$ e $50,42 \%$ para castrados e $1,284 \mathrm{~kg}$ e $51,52 \%$ para não-castrados e concluíram que mestiços Holandês x Zebu podem ser confinados aos 17 meses de idade e usados como produtores de carne.

LORENZONI et al. (1986) observaram ganhos de peso médios diários de 0,$87 ; 0,96 ; 0,98 ; 0,97$ e 1,05 para novilhos das raças Nelore, Holandês, 1/2 Holandês x Zebu, 3/4 Holandês x Zebu e 5/8 Holandês x Zebu, respectivamente. ARANOVICH et al. (1981) observaram maior ganho de peso em mestiços com alta percentagem de sangue Holandês que em animais $\mathrm{F}_{1}$ Zebu x Holandês e Zebu.

MORAIS et al. (1993) verificaram em bovinos 3/4 Gir x Holandês ganhos diários de 1,03 kg para animais inteiros e $0,76 \mathrm{~kg}$ para animais castrados.

PERRY e FOX (1992), comparando novilhos da raça Holandesa com animais de raças de corte (Angus, Simental e Angus x Simental), encontraram ganhos médios diários de 1,23 kg para novilhos holandeses e 1,24 kg para os de corte e rendimentos de carcaça de 59,0 e $61,6 \%$, respectivamente.

Vários autores comparando animais Nelore com mestiços de aptidão leiteira (LORENZONI et al., 1986; PERON et al., 1993; JORGE, 1993) e taurinos (ALLEONI et al., 1981; MOLETTA e RESTLE; 1992, MOLLETTA e RESTLE, 1996) observaram maiores rendimentos de carcaça nos primeiros. Os rendimentos de carcaça mais elevados observados entre zebuínos são atribuídos, por WESTON (1982), ao fato de os mesmos possuírem baixos pesos de conteúdo do trato gastrintestinal e menores vísceras.

Embora as pesquisas demonstrem, claramente, $o$ grande potencial para produção de carne de bezerros de raças leiteiras de grande porte, não há, ainda, informações suficientes, em condições brasileiras, sobre os reflexos do regime alimentar imposto aos animais durante a cria, sobre o seu desempenho.

Após período de restrição nutricional, no qual o peso vivo dos animais aumenta pouco, mantém-se inalterado ou reduz-se, pode ocorrer taxa de crescimento mais rápida, possibilitando, ou não, a recuperação do peso, em relação a animais não submetidos à restrição. Em geral, bovinos submetidos à restrição alimentar logo após o nascimento não apresentam ganho compensatório, podendo ter o seu desenvolvimento permanentemente comprometido (RYAN, 1990).

O objetivo da presente pesquisa foi avaliar, em confinamento, o ganho de peso e a eficiência alimentar, bem como as características da carcaça de novilhos originários de rebanho leiteiro, submetidos à desmama precoce e à dieta rica em volumoso, durante a fase de cria.

\section{Material e Métodos}

O presente experimento foi realizado no período de 9 de novembro de 1992 a 29 de julho de 1993. Foram utilizados 16 novilhos machos, castrados, holandeses puros por cruza (HPC) e mestiços 7/8 e 15/16 Holandês x Zebu, com idade e peso vivo inicial médios de 20 meses e $202,0 \mathrm{~kg}$, respectivamente, originários do rebanho pertencente ao Departamento de Zootecnia (DZO), da Universidade Federal de Viçosa. Durante a fase de cria, os animais foram submetidos a aleitamento artificial, com desmama aos 56 dias de idade. Após a desmama, permaneceram em piquete provido de coberta, recebendo capim-napier picado e, até os 120 dias de idade, suplemento concentrado, na base de $1,0 \mathrm{~kg}$ por cabeça por dia. A partir dos 6 meses de idade, receberam, basicamente, pasto mais suplemento volumoso na seca.

No período seco anterior ao experimento, os animais permaneceram em piquete, recebendo silagem de capim-elefante (Pennisetum purpureum, Schum), suplemento mineral e, nos últimos trinta dias, suplemento concentrado. Antes do início do experimento, foram identificados com brincos numerados e tratados contra ecto e endoparasitas. Durante o experimento, os animais foram mantidos em regime de confinamento, em baias individuais de piso concretado, com área de $8 \mathrm{~m}^{2}$ por animal, em galpão de alvenaria coberto.

O período de adaptação às instalações teve duração de 12 dias, uma vez que os animais estavam adaptados a regime alimentar semelhante ao utilizado no experimento. Nesse período, todos os animais receberam a mesma ração ad libitum.

Após o período de adaptação, quatro novilhos foram abatidos (grupo AI), determinando-se composição corporal, em termos de gordura e proteína, peso corporal vazio (PCVZ), além da relação média entre seu PCVZ e o peso vivo, que foi utilizada para se estimar o PCVZ inicial dos animais remanescentes. Estes últimos foram divididos em três grupos, uniformes quanto ao peso vivo e à condição corporal, recebendo aleatoriamente os tratamentos: 
150 Rev. bras. zootec.

AL-1: Ração ad libitum até o abate aos $250 \mathrm{~kg}$ de peso vivo (AL-1);

AL-2: Ração ad libitum até o abate aos $300 \mathrm{~kg}$ de peso vivo (AL-2); e

AL-3: Ração ad libitum até o abate aos $350 \mathrm{~kg}$ de peso vivo (AL-3).

A ração foi formulada segundo as normas do NRC (1984) para possibilitar aos animais AL-1, AL2 e AL-3 ganho de peso diário de $1,0 \mathrm{~kg}$, atendendo, ao mesmo tempo, às exigências de proteína degradável no rúmen (PDR) e proteína não-degradável no rúmen (PNDR), segundo o ARC (1980).

A ração constituída de silagem de capim-elefante, fubá de milho, farelo de soja, uréia e premix vitamínico-mineral foi fornecida uma vez ao dia, no período da manhã, procurando-se manter a proporção de concentrado:volumoso próxima de 1:1, na base da matéria seca (MS).

A composição percentual da ração experimental é apresentada na Tabela 1 e os conteúdos de energia metabolizável, proteína bruta e macroelementos minerais na matéria seca da silagem, do concentrado e da ração encontram-se na Tabela 2.

Para os lotes que receberam ração ad libitum, a quantidade oferecida foi ajustada, de forma a se manterem as sobras individuais entre 5 e $10 \%$ da oferta. As quantidades de ração fornecida e de sobras foram registradas, diariamente, e amostras da ração e individuais das sobras foram coletadas, semanalmente, congeladas e armazenadas a $-15^{\circ} \mathrm{C}$ para análises químicas posteriores.

As amostras semanais de ração e sobras individuais foram agrupadas em amostras compostas mensais, de forma proporcional, sendo submetidas à pré-
Tabela 1 - Composição percentual da ração experimental (base da MS)

Table 1- Percentage composition of the experimental ration (DM basis)

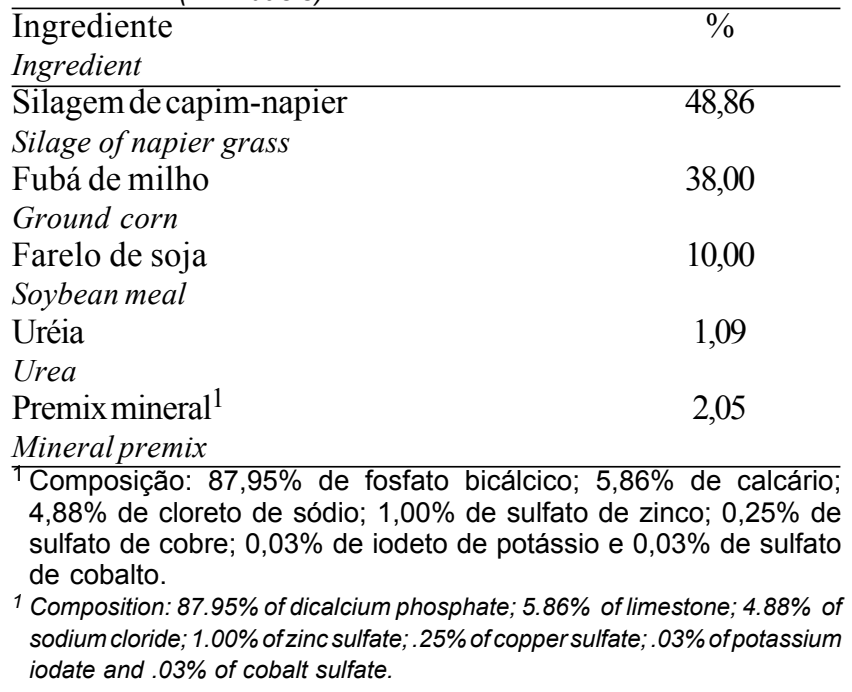

secagem em estufa de ventilação forçada à temperatura de $50-60^{\circ} \mathrm{C}$, durante 72 horas. Em seguida, foram moídas em moinho tipo "Willey", com peneira de 30 mesh e acondicionadas em vidros para análises químicas posteriores.

O período experimental não teve duração préestabelecida. Os animais foram abatidos assim que atingiam os pesos individuais pré-estabelecidos de 250,$0 ; 300,0$; e $350,0 \mathrm{~kg}$, correspondentes aos tratamentos AL-1, AL-2 e AL-3, respectivamente. Os animais eram pesados periodicamente, de forma que cada animal pudesse ser abatido o mais próximo possível do peso pré-estabelecido.

Os animais foram abatidos após jejum de 16

Tabela 2 - Teores de matéria seca (MS), proteína bruta (PB), energia metabolizável (EM), cálcio (Ca), fósforo $(\mathrm{P})$, magnésio $(\mathrm{Mg})$, sódio $(\mathrm{Na})$ e potássio $(\mathrm{K})$ dos ingredientes e da ração experimental (base da MS) 1

Table 2 - Contents of dry mater (DM), crude protein (CP), metabolizable energy (ME), calcium (Ca), phosphorum $(P)$, magnesium $(\mathrm{Mg})$, sodium $(\mathrm{Na})$ and potassium $(\mathrm{K})$ of the ingredients and of the experimental diet (DM (basis) ${ }^{1}$

\begin{tabular}{|c|c|c|c|c|c|c|c|c|}
\hline $\begin{array}{l}\text { Ingrediente } \\
\text { Ingredient }\end{array}$ & $\begin{array}{c}\mathrm{MS}(\%) \\
D M\end{array}$ & $\begin{array}{c}\mathrm{PB}(\%) \\
C P\end{array}$ & $\begin{array}{l}\mathrm{EM}^{2} \\
M E^{2}\end{array}$ & $\mathrm{Ca}(\%)$ & $\mathrm{P}(\%)$ & $\operatorname{Mg}(\%)$ & $\mathrm{Na}(\%)$ & $\mathrm{K}(\%)$ \\
\hline $\begin{array}{l}\text { Silagem } \\
\text { Silage }\end{array}$ & 45,00 & 3,14 & - & 0,28 & 0,10 & 0,39 & 0,02 & 0,53 \\
\hline $\begin{array}{l}\text { Concentrado } \\
\text { Concentrate }\end{array}$ & 87,94 & 19,86 & - & 0,95 & 0,85 & 0,13 & 0,14 & 0,68 \\
\hline $\begin{array}{l}\text { Ração total } \\
\text { Total diet } \\
\text { Tot }^{3}\end{array}$ & - & 12,48 & 1,88 & 0,63 & 0,49 & 0,24 & 0,08 & 0,53 \\
\hline
\end{tabular}

${ }^{1}$ Análises realizadas no Laboratório de Nutrição Animal do Departamento de Zootecnia da UFV.

2 Mcal de EM/kg de MS.

${ }^{3}$ Valores estimados a partir da composição da silagem e dos ingredientes do concentrado.

${ }^{1}$ Analyses performed at Animal Nutrition Lab of Animal Science Department of UFV.

${ }^{2} \mathrm{Mcal}$ of $\mathrm{ME} / \mathrm{kg}$ of $\mathrm{DM}$.

${ }^{3}$ Values estimated from composition of silage and of components of the concentrate. 
ROCHA et al.

horas. $\mathrm{Na}$ ocasião, foram pesados e amostrados rúmen-retículo, omaso, abomaso, intestinos delgado e grosso, após serem esvaziados e lavados, obtendose, ainda, os pesos e as amostras de sangue, couro, pés, cabeça, cauda, órgãos e carcaça.

Os pesos das vísceras foram somados aos pesos dos demais componentes do corpo, obtendo-se o peso corporal vazio (PCVZ) de cada animal.

Para a conversão de PV em PCVZ, dentro do intervalo de pesos incluídos no estudo, utilizou-se a equação obtida por regressão do PCVZ dos 16 animais utilizados no experimento, em função do $\mathrm{PV}$ dos mesmos.

As duas meias-carcaças foram pesadas no dia do abate e, posteriormente, armazenadas em câmara fria a $-5^{\circ} \mathrm{C}$, durante período de 18 horas, após o qual foram novamente pesadas e processadas.

Os rendimentos de carcaça quente e fria foram determinados e expressos em percentagem do peso vivo e do peso corporal vazio.

Para o estudo do rendimento dos cortes primários, utilizou-se a meia-carcaça direita, separando-se o dianteiro do traseiro entre a quinta e a sexta costelas. $\mathrm{O}$ dianteiro compreendeu a acém e paleta completos. $\mathrm{O}$ traseiro foi dividido em ponta de agulha e traseiro especial, este último dividido em coxão e alcatra completa.

As análises de variância foram feitas segundo o modelo geral:

em que

$$
\mathrm{Y}_{\mathrm{ij}}=\mu+\mathrm{T}_{\mathrm{i}}+\mathrm{e}_{\mathrm{ij}} \text {, }
$$

$\mathrm{Y}_{\mathrm{ij}}=$ observação referente ao animal $\mathrm{j}$, da categoria $\mathrm{i}$;

$\mu=$ efeito da média;

$\mathrm{T}_{\mathrm{i}}=$ efeito do tratamento, sendo $\mathrm{i}=1,2,3$ e 4 , em que $1=$ animais referência $\mathrm{AI} ; 2=$ animais $\mathrm{AL}-1 ; 3=$ animais AL-2; 4= animais AL-3; e

$\mathrm{e}_{\mathrm{ij}}=$ erro aleatório, pressuposto normalmente distribuído, com média zero e variância $\sigma^{2}$.

As médias foram comparadas pelo teste de Newman Keuls (STEEL e TORRIE, 1960) a 5\% de probabilidade.

O efeito do peso de abate sobre características quantitativas da carcaça foi, ainda, avaliado por meio de análise de regressão.

\section{Resultados e Discussão}

A Tabela 3 mostra as médias para consumo diário de matéria seca (CMS), ganho de peso e conversão alimentar (CA) de novilhos dos grupos AL-1, AL-2 e AL-3, durante o período experimental.

Não houve diferença entre os três grupos, quanto aos valores de consumo médio diário de matéria seca, expressos em kg/dia, por $\mathrm{kg}^{0,75}$ e por $100 \mathrm{~kg}$ de PV. Não foram, igualmente, verificadas diferenças entre tratamentos, quanto ao ganho de peso. Entretanto, animais do grupo AL-1, embora tenham apresentado menores valores numéricos de consumo (total, por $100 \mathrm{~kg}$ de PV e por $\mathrm{kg}^{0,75}$ ), mostraram maiores valores numéricos de ganho de peso vivo (GPV) e ganho de PCVZ (GPCVZ), o que sugere influência do ganho compensatório, que tende a ocorrer quando animais submetidos a níveis nutricionais baixos ou moderados passam a receber nível nutricional mais elevado (RYAN, 1990, HOGG, 1991 e PATTERSON et al., 1995). Nos animais AL-1, abatidos em período mais curto após a elevação do nível nutricional, o

Tabela 3 - Médias para consumo diário de matéria seca e desempenho dos novilhos, abatidos com diferentes pesos

Table 3 - $\quad$ Means for daily intake of dry matter and performance traits of dairy steers, slaughtered at different weights

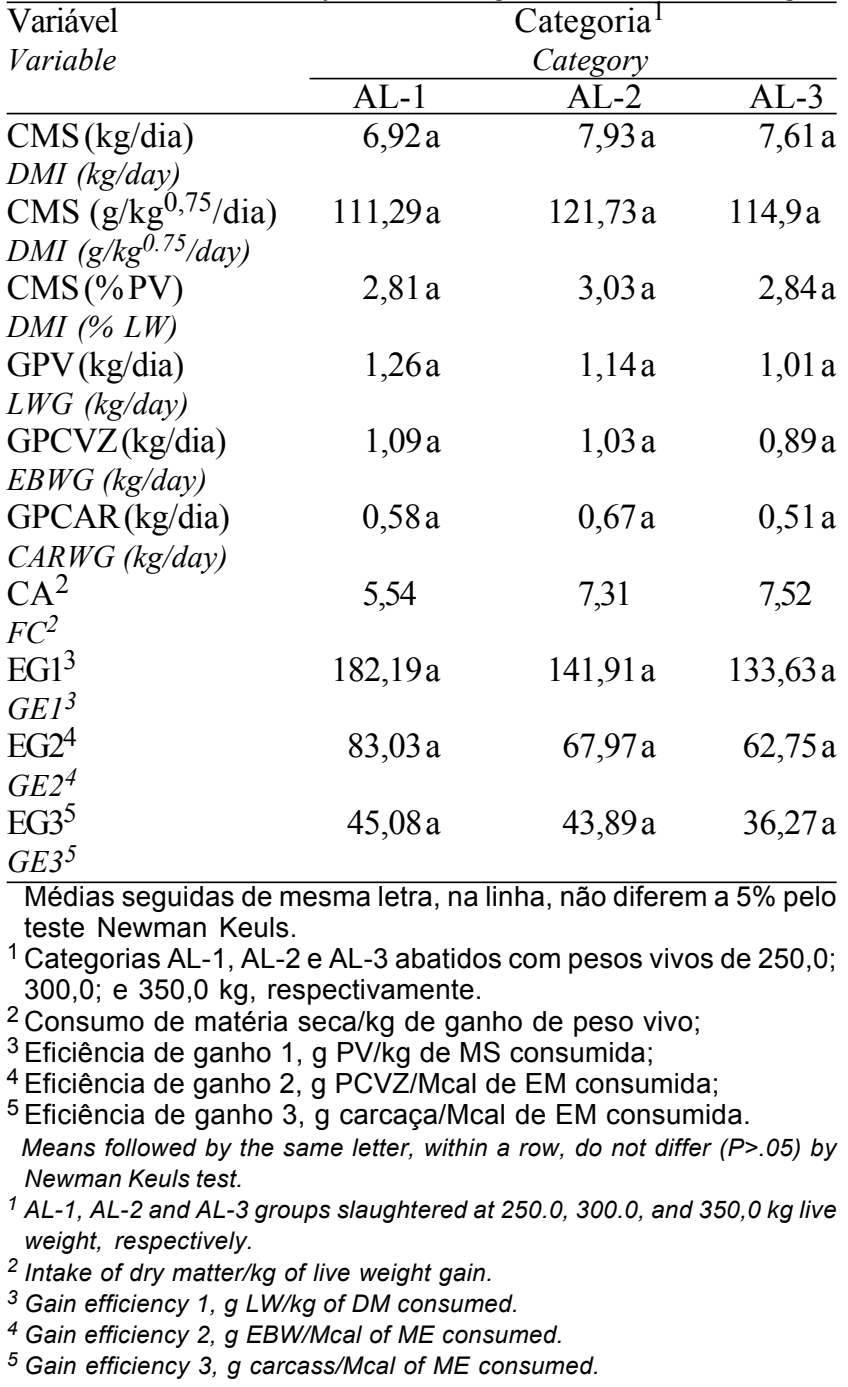


152 Rev. bras. zootec.

efeito do ganho compensatório seria mais nítido.

De acordo com CSIRO (1990), grande parte do ganho compensatório traduz-se na forma de aumento do conteúdo do trato gastrintestinal e do peso dos órgãos internos. Os resultados obtidos no presente trabalho são atribuídos ao fato de as diferenças aparentes no ganho de peso vivo, a favor dos animais AL-1, não terem se mantido, quando se consideraram GPCVZ e ganho de peso de carcaça (GPCAR). Devese ainda ressaltar que os animais utilizados no presente trabalho foram machos de origem leiteira, criados com restrição de leite e pouco concentrado na fase anterior ao experimento, condição que os predispõe ao ganho compensatório no início da fase experimental.

Com relação à conversão alimentar (CA), o melhor desempenho correspondeu aos animais AL-1, provavelmente por apresentarem menores exigências de energia para mantença, devido ao menor porte e à menor exigência energética por $\mathrm{kg}$ de ganho de peso, em razão de menor deposição de gordura corporal e maior acúmulo de músculos.

A conversão alimentar é altamente influenciada pela natureza da dieta, pela composição corporal do animal e pelo ganho de peso. De modo geral, os resultados de conversão alimentar observados no presente trabalho (kg de alimento por $\mathrm{kg}$ de ganho) são melhores que os relatados por HOOVEN JUNIOR et al. (1972), que trabalhando com animais de várias raças (Angus, Hereford, Holstein x Friesian, Jersey e Shorthorn leiteira), obtiveram CA média de 9,89 e 9,27, para animais recebendo baixo e alto nível de nutrição, respectivamente. MATTOS et al. (1974), trabalhando com animais $1 / 2$ Suíço x Guzerá, observaram CA média de 13,17 e 10,27, para novilhos que receberam rações com ou sem excrementos de aves, respectivamente. Entretanto, resultados próximos aos deste experimento foram relatados por BARBER et al. (1981), que estudaram os efeitos do peso ao abate e da densidade energética da dieta sobre o ganho de peso e da carcaça de novilhos, encontrando CA de 6,43; 7,51; 8,36; 6,14; 7,10; e 7,65, para novilhos Charoleses e Angus, abatidos, respectivamente, com pesos vivos correspondentes a 86,100 e $114 \%$ dos pesos à maturidade das fêmeas das respectivas raças.

Tabela 4 - Médias para proporções dos tecidos muscular (M), adiposo (TA) e ósseo (O) e relações tecido mole ${ }^{1}$ osso (TM/O), músculo/osso (M/O), tecido adiposo/osso (TA/O), tecido adiposo/músculo (TA/M) e área de lombo ( $\mathrm{AL}$ ) nas carcaças dos novilhos abatidos com diferentes pesos vivos ${ }^{2}$

Table 4 - $\quad$ Means for proportions of the muscle $(M)$, fatty $(F)$ and bone $(B)$ and relations between soft tissue ${ }^{1 /}$ bone (ST/B), muscle/bone (M/B), fat tissue/bone (FT/B), fat tissue/muscle (FT/M) and rib eye area (REA) in the carcasses of steers slaughtered at different live weights ${ }^{2}$

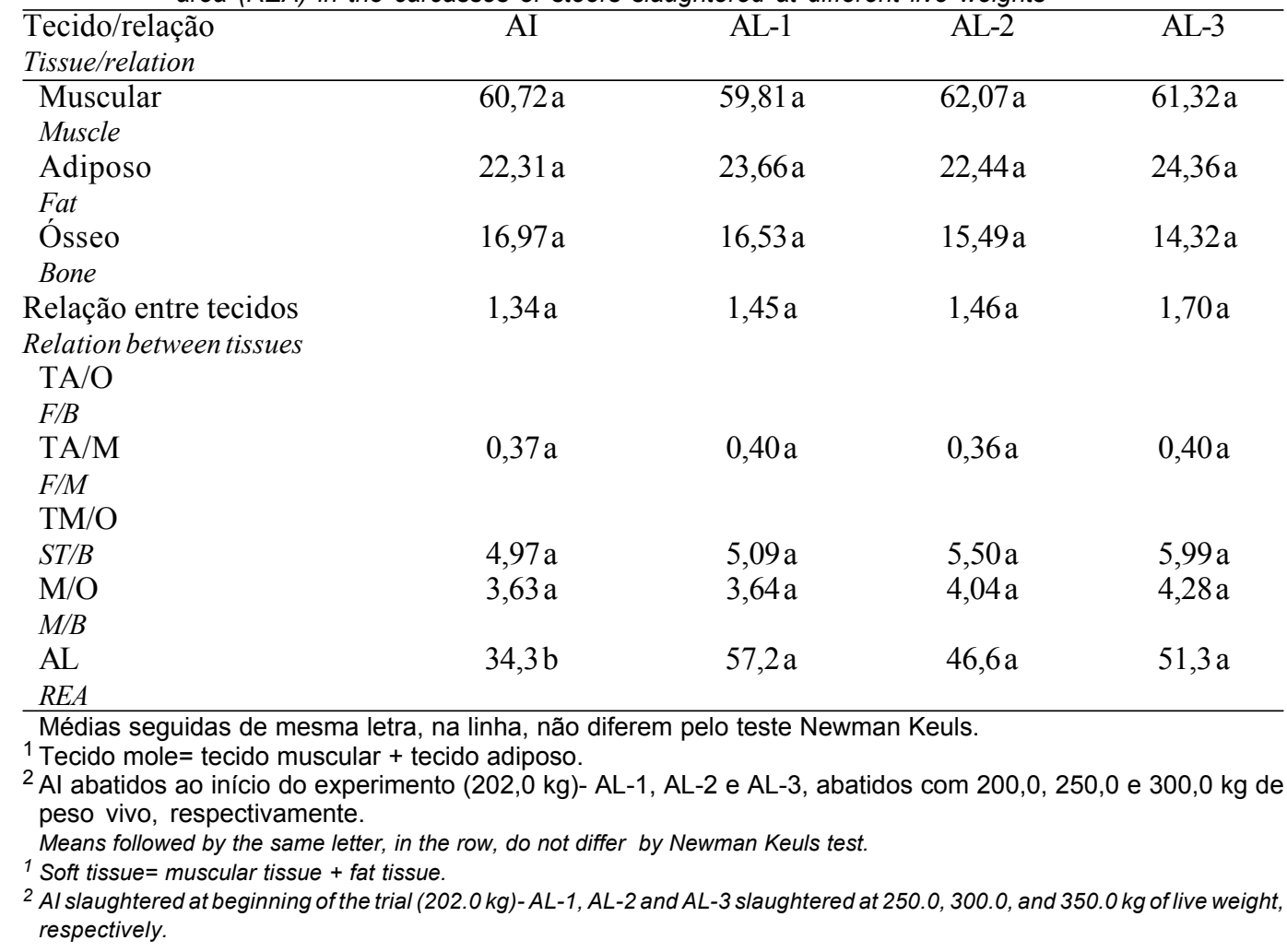


O melhor desempenho geral dos animais deste trabalho, em relação aos trabalhos anteriormente citados, estaria, provavelmente, relacionado ao menor peso de abate dos animais e, conseqüentemente à sua menor exigência de mantença e menor acúmulo de gordura e maior de proteína corporal; em alguns casos, a diferenças na natureza das dietas.

As eficiências de utilização da MS e energia alimentares para ganho de peso não diferiram entre tratamentos, embora maiores valores de ganho, por unidade de consumo de MS e EM, correspondam a animais mais leves.

Resultados semelhantes aos obtidos neste experimento foram observados por JORGE (1997) e PATTERSON et al. (1994), que verificaram decréscimo na eficiência de utilização da energia metabolizável para ganho de PCVZ e carcaça, com aumento do peso de abate. Essa queda de eficiência pode ser atribuída a maiores acúmulo de gordura e exigências de mantença em animais mais pesados.

PATTERSON et al. (1995) observaram que animais, após período de restrição alimentar, tiveram melhor eficiência de conversão alimentar durante o período de ganho compensatório.

A Tabela 4 mostra as médias para proporções dos tecidos corporais e as relações entre os mesmos, para os novilhos abatidos com diferentes pesos vivos.

Não foram verificadas diferenças entre tratamentos, quanto às proporções dos tecidos muscular, adiposo e ósseo. A análise de regressão não mostrou efeito do peso de abate do animal, na faixa de peso considerada no presente experimento, sobre as proporções dos três tecidos. A única tendência revelada de forma consistente $(\mathrm{P}<0,07)$ foi a de queda da percentagem de ossos, com a elevação do peso do animal. Esta tendência seria conseqüência de o tecido ósseo atingir a maturidade em idade mais precoce que os tecidos muscular e adiposo, o que acarretou aumento nas relações tecido adiposo:osso, tecido mole:osso e músculo:osso, com a elevação do peso do animal. Neste experimento, os animais abatidos com pesos mais elevados estavam ainda em plena fase de crescimento muscular, não ocorrendo, dessa forma, elevação da proporção de gordura (de desenvolvimento mais tardio) naqueles abatidos com peso mais elevado, justificando a não ocorrência de mudança na proporção de músculos com o aumento do peso do animal.

Estes resultados confirmam as observações de MARQUAT (1964) de que somente ocorre aumento na percentagem de gordura na carcaça de novilhos de raças leiteiras, após os mesmos atingirem, em média, 454,0 kg de PV.
As percentagens de músculo na carcaça, no presente trabalho, são, de modo geral, superiores ao valor de 52,03\% encontrado por PERON et al. (1995), enquanto as de tecido adiposo e ossos são inferiores aos valores de 30,4 e 17,3\%, respectivamente, observados pelos mesmos autores, para novilhos 3/4 Holandês x Zebu, castrados, abatidos com pesos mais elevados. CASTILLO ESTRADA (1996), entretanto, verificou valores semelhantes aos dos animais do presente trabalho para proporção de tecidos muscular $(60,40)$, adiposo $(25,47)$ e ósseo $(14,13)$ em animais mestiços, abatidos com pesos mais elevados. São também próximos aos de GALVÃO et al. (1991), que verificou proporções de músculo de 64,$49 ; 64,35$; e 61,26; tecido adiposo de 22,58; 24,80; e 26,99 e ossos de 15,$92 ; 14,31$; e 14,93\% em animais zebuínos, abatidos com pesos correspondentes a 90, 100 e $110 \%$ dos pesos vivos estimados à maturidade das vacas da raça.

De modo semelhante ao observado no presente trabalho, JORGE (1997), estudando características de carcaça de zebuínos inteiros abatidos em diferentes estádios de maturidade fisiológica, encontrou maior relação TA/O em animais mais pesados.

Para a relação tecido adiposo:muscular (TA/M), a inexistência de diferenças entre animais abatidos com diferentes pesos vivos indica que esses tecidos cresceram a taxas semelhantes, dentro da faixa de peso estudada. Quando os animais são abatidos em estádios mais avançados de maturidade fisiológica, espera-se aumento da citada relação com a elevação do peso de abate, conforme verificado por JORGE (1997), ao se compararem animais abatidos com pesos entre 300,0 e $500,0 \mathrm{~kg}$.

$\mathrm{O}$ aumento verificado na relação músculo:osso (M/O), com o aumento do peso de abate, coincide com os resultados de JORGE $(1993,1997)$ e reflete, basicamente, a maturação mais precoce (redução da taxa de crescimento) do tecido ósseo, igualmente observada por GALVÃO et al. (1991), PERON et al. (1995) e CASTILLO ESTRADA (1996), em concordância com BERG e BUTTERFIELD (1976).

Em conseqüência das mudanças nas relações M/O e TA/O, ocorreu igualmente aumento da relação tecido mole:osso (TM/O) com a elevação do peso de abate, coincidindo com os resultados de JORGE (1997), refletindo a maturação mais precoce do tecido ósseo. Quanto à área de lombo ( $\mathrm{AL})$, não houve diferença entre animais de abate inicial e os AL-1 e entre os AL-2 e AL-3, tendo os dois últimos diferido $(\mathrm{P}<0,05)$ dos dois primeiros. A tendência de aumento na AOL, a cada aumento do peso de abate do animal, 
154 Rev. bras. zootec.

foi confirmada pela análise de regressão, que mostrou ocorrer aumento $(\mathrm{P}<0,05)$ da AOL com a elevação do PCVZ.

Ao abater bezerros holandeses com peso médio de $190,0 \mathrm{~kg}$ (valor próximo aos animais AL-1 do presente trabalho), RIBEIRO (1997) encontrou valores de área de lombo de 29,60;32,19;34,78 e 37,38 $\mathrm{cm}^{2}$, para animais alimentados com rações contendo, respectivamente, 45, 60, 75 e $90 \%$ de concentrado.

$\mathrm{O}$ aumento da AOL, em animais em crescimento, com a elevação do peso de abate, é conseqüência direta e esperada do crescimento de todos os tecidos corporais, tendo sido igualmente relatado por BERG e BUTTERFIELD (1976), JORGE (1993) e PERON et al. (1995) e JORGE (1997).

A Tabela 5 mostra as médias para rendimentos de carcaça e de seus cortes básicos em relação ao PCVZ, para novilhos abatidos com os diferentes pesos.

Para os rendimentos de carcaça quente e fria, não foram verificadas diferenças entre tratamentos. A análise de regressão revelou não existir influência do PCVZ sobre os rendimentos de carcaça, na faixa de peso estudada.

Quando bovinos são abatidos com pesos mais elevados, tem-se observado aumento do rendimento de carcaça, com a elevação do peso de abate, principalmente em virtude do menor peso relativo dos órgãos internos em animais maiores, conforme observado por JORGE (1993), uma vez que os órgãos atingem a maturidade, parando de crescer mais precocemente que os tecidos da carcaça.

O maior rendimento de carcaça, com o aumento do peso e da espessura de gordura subcutânea do animal, foi demonstrado por PRESTON e WILLIS (1974).

A inexistência de influência do PCVZ sobre o rendimento de carcaça, no presente estudo, pode, portanto, ser atribuída ao baixo peso de abate dos animais, mesmo dos abatidos com pesos mais elevados. O aumento do teor de gordura da carcaça e a redução proporcional das vísceras são observados, de forma mais nítida, normalmente, em animais abatidos com pesos mais elevados, conforme verificado por JORGE (1993) e comentado por BERG e BUTTERFIELD (1976).

Os rendimentos de carcaça observados neste experimento são superiores aos de MATTOS et al. (1977), que verificaram rendimentos de carcaça fria crescentes, de 54,07 a $55,58 \%$, à medida que se

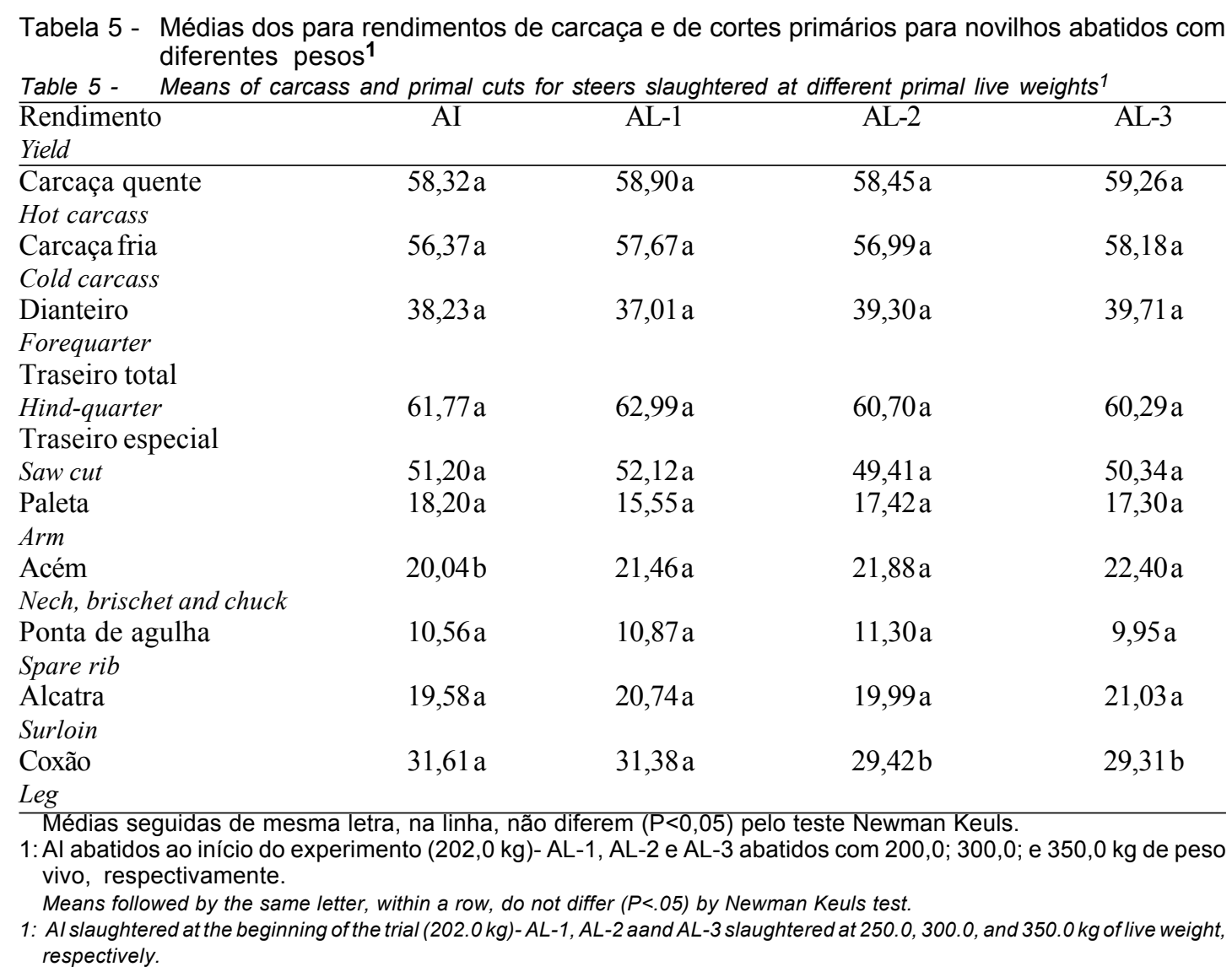


elevou o peso de abate dos animais.

Resultados próximos aos deste trabalho foram relatados por RIBEIRO (1997), para animais holandeses abatidos, em média, com 190,0 kg de peso vivo. Esse autor encontrou valores de rendimentos de carcaça quente de 58,$13 ; 57,90 ; 57,65$ e 57,41\%, para animais alimentados com rações contendo, respectivamente, 45,60 , 75 e $90 \%$ de concentrado e rendimento de carcaça fria constante de $56,31 \%$, para os mesmos animais.

PERON et al. (1993), GALVÃO et al. (1991) e JORGE (1993), que abateram animais com pesos mais elevados, observaram maiores rendimentos de carcaça, em relação ao PCVZ, que os deste trabalho. Considerando o rendimento de carcaça em relação ao peso vivo, MOLETTA e RESTLE (1996) encontraram rendimento de carcaça fria de 50,05; 50,29 e $53,81 \%$, para novilhos das raças Charolesa, Angus e Nelore, respectivamente, abatidos, em média, com 415,0 kg de PV.

Quanto à quebra de peso da carcaça por resfriamento (QR), também não foram verificadas diferenças entre tratamentos, tendo a análise de regressão mostrado tendência $(\mathrm{P}<0,10)$ de menor quebra em animais mais pesados.

A quebra por resfriamento (QR) está intimamente relacionada à gordura de cobertura da carcaça, sendo maior nas de menor cobertura, conforme salienta JORGE (1997). Para esse autor, certa quantidade de gordura é desejável, pois a mesma tem a função de proteger as carcaças contra o ressecamento causado pelo resfriamento.

Os resultados obtidos neste experimento para QR, são, de modo geral, próximos aos de RIBEIRO (1997), que encontrou valores de QR de 3,26; 2,30; 1,97; e 2,29\%, para animais holandeses alimentados com rações, contendo, respectivamente, 45, 60, 75 e 90\% de concentrado e abatidos, em média, com 190,0 kg.

Não houve diferença entre tratamentos quanto aos rendimentos de dianteiro e traseiro total. A análise de regressão não revelou, igualmente, influência do peso de abate sobre os rendimentos dos dois cortes básicos. Os baixos pesos de abate dos animais e o fato de os mesmos serem castrados explicam a inexistência de diferenças entre balanço de dianteiro e traseiro, nos animais dos vários tratamentos.

Os resultados de rendimentos de traseiro e dianteiro observados neste experimento são, de modo geral, próximos aos de RIBEIRO (1997), para animais Holandeses abatidos, em média, com 190,0 kg de peso vivo. Esse autor encontrou valores de ren- dimentos de traseiro total de 60,$92 ; 61,89 ; 61,96$; e $60,90 \%$, para animais alimentados com rações contendo, respectivamente, $45,60,75$ e $90 \%$ de concentrado e rendimentos de dianteiro de 39,$8 ; 38,1 ; 38,04$; e 39,1 , para os mesmos tratamentos, respectivamente.

De forma semelhante, os valores de rendimento de dianteiro são próximos aos valores de 38,2 e 38,4\% encontrados por RESTLE et al. (1996), para novilhos Nelore x Charolês, castrados e inteiros, respectivamente, abatidos, com maiores pesos vivos (450,0 kg de média).

Comparando os rendimentos de dianteiro e traseiro de animais zebuínos abatidos com pesos vivos entre 300,0 e 500,0 kg, JORGE (1993) encontrou pequena variação nesses rendimentos, salientando que as diferenças observadas tinham pequeno significado biológico ou econômico.

Para os rendimentos de traseiro especial e ponta de agulha, que compõem o traseiro total, também não houve diferenças entre tratamentos. A análise de regressão não apresentou efeito do PCVZ sobre os rendimentos dos dois cortes, na faixa de peso estudada.

Os resultados obtidos para rendimento de traseiro especial, neste experimento, são superiores aos de MATTOS et al. (1977), que encontraram rendimentos de 42,90 e 41,61\% para animais Nelore abatidos aos 26 e 32 meses de idade, respectivamente. São, ainda, ligeiramente mais elevados que os valores de 47,9 e 48,1\% observados por RESTLE et al. (1996), para novilhos Nelore x Charolês, castrados e nãocastrados, respectivamente, abatidos, com maiores pesos vivos (450,0 $\mathrm{kg}$ de média).

Resultados semelhantes aos obtidos neste experimento, para rendimento de traseiro especial e ponta de agulha, foram observados por JORGE (1997) e RIBEIRO (1997).

Quanto ao rendimento de paleta completa, não houve diferenças entre tratamentos. Os valores observados neste experimento foram, de modo geral, próximos aos de RIBEIRO (1997), para animais holandeses abatidos, em média, com 190,0 kg de peso vivo. Esse autor encontrou valores de rendimentos de paleta de 20,$24 ; 19,43 ; 19,06$ e 19,13\%, para animais alimentados com rações contendo, respectivamente, $45,60,75$ e $90 \%$ de concentrado.

Valores mais baixos para rendimento de paleta, de 13,9 e 13,5\%, foram observados por RESTLE et al. (1996), em novilhos Nelore x Charolês, castrados e inteiros, respectivamente, abatidos, com maiores pesos vivos (450,0 kg, em média). Os mais baixos valores percentuais observados por esses autores podem ser, parcialmente, atribuídos ao abate dos 
156 Rev. bras. zootec.

animais em fase mais avançada de maturidade, em que o crescimento dos membros desacelera, em relação ao tronco do animal.

Para o rendimento de acém completo, houve diferenças $(\mathrm{P}<0,05)$ entre tratamentos, sendo maior nos animais AL-1, AL-2 e AL-3, em relação aos AI. $\mathrm{A}$ análise de regressão revelou efeito do $\mathrm{PCVZ}$ $(\mathrm{P}<0,05)$ sobre o rendimento do acém. Estes resultados eram previsíveis, já que músculos do acém completo tendem a ser mais desenvolvidos em animais abatidos com maiores pesos vivos.

Os resultados obtidos neste experimento são, de modo geral, próximos aos de RIBEIRO (1997), referentes a animais Holandeses abatidos, em média, com 190,0 $\mathrm{kg}$ de peso vivo. Esse autor encontrou valores de rendimentos de acém completo de 18,$57 ; 18,38 ; 18,78$; e $19,77 \%$, para animais alimentados com rações contendo, respectivamente, $45,60,75$ e $90 \%$ de concentrado.

Não houve diferenças entre tratamentos, quanto ao rendimento de alcatra completa, não tendo a análise de regressão mostrado qualquer influência do PCVZ sobre o rendimento do corte.

Quanto ao rendimento de coxão, as médias para animais $\mathrm{AI}$ e $\mathrm{AL}-1$ foram maiores $(\mathrm{P}<0,05)$ que as referentes a animais AL-2 e AL-3. A influência do peso do animal sobre o rendimento de coxão foi obtida por meio da análise de regressão, que indicou queda do rendimento $(\mathrm{P}<0,05)$ com elevação do PCVZ.

RIBEIRO (1997) observou rendimentos de coxão de 31, 16; 30,87; 31,27 e 30,45\%, em animais Holandeses abatidos, em média, com 190,0 kg de PCVZ e alimentados com rações contendo, respectivamente, $45,60,75$ e $90 \%$ de concentrado. PERON et al. (1993), entretanto, verificaram tendência de redução do rendimento de coxão com aumento do peso vivo, contrapondo-se aos rendimentos crescentes do acém completo.

A Tabela 6 mostra as equações de predição dos pesos da carcaça quente e fria a partir do peso corporal vazio do animal.

Os resultados obtidos neste experimento mostram que o peso corporal vazio (PCVZ) foi responsável por 98 e $97 \%$ das variações totais dos pesos da carcaça quente e fria, respectivamente. Os coeficientes de regressão indicaram que, a cada quilograma de aumento no peso vivo, os pesos de carcaça quente e fria aumentaram 0,594 e 0,595 kg, respectivamente. Estes valores são pouco inferiores aos de CASTILLO ESTRADA (1996) e JORGE (1997), que observaram valores próximos a 0,65 , para coeficientes de regressão dos pesos de carcaças quentes e frias, em função do PCVZ. No presente experimento, os animais foram abatidos com pesos muito inferiores aos adotados nos trabalhos anteriormente citados. Portanto, os animais deste estudo, menos maturos, fisiologicamente, encontravam-se em fase de crescimento mais acentuado dos órgãos, com crescimento relativo da carcaça menos acentuado.

Os coeficientes de determinação $\left(\mathrm{R}^{2}\right)$ das equações de regressão ajustadas para pesos das carcaças quente (PCARQ) e fria (PCARF), em função do PCVZ, indicaram seu bom ajustamento aos dados, de forma semelhante ao verificado por CASTILLO ESTRADA (1996) $\left(\mathrm{R}^{2}\right.$ de 0,96 , para carcaça fria e quente).

Utilizando-se os 16 animais do experimento, obteve-se a equação de predição do peso corporal vazio (PCVZ), em função do peso vivo (PV):

$\mathrm{PCVZ}=-20,8986+0,89178649 \times \mathrm{PV}, \mathrm{R}^{2}=0,99$

O elevado valor do coeficiente de determinação $\left(\mathrm{R}^{2}=0,99\right)$ mostra bom ajustamento da equação aos dados experimentais.

Utilizando-se a equação acima, estimou-se, para um animal com PV de $300 \mathrm{~kg}, \mathrm{PCVZ}$ de $246,6 \mathrm{~kg}$. Este valor é semelhante ao estimado para animais zebuínos de mesmo peso por PAULINO (1996), sendo 3,8 e 1,3\% inferiores aos obtidos por LANA et al. (1992a) e FONTES (1995), respectivamente, para animais mestiços Europeu x Zebu castrados e 0,7\% inferior ao estimado por JORGE (1997), para animal zebuíno nãocastrado, de mesmo peso vivo.

Tabela 6 - Equações de predição dos pesos $(\mathrm{kg})$ da carcaça quente (PCARQ) e da carcaça fria (PCARF) em função do peso de corpo vazio (PCVZ)

Table 6 - Prediction equations of the weight $(\mathrm{kg})$ of the hot carcass (HCW) and of the cold carcass (CCW) in function of the empty body weight (EBW)

\begin{tabular}{lcc}
\multicolumn{3}{c}{ function of the empty body weight (EBW) } \\
\hline \multicolumn{2}{c}{$\begin{array}{c}\text { Equação } \\
\text { Equation }\end{array}$} & $\mathrm{R}^{2}$ \\
\hline \multicolumn{2}{c}{ Rendimento da carcaça } \\
Carcass yield \\
\hline PCARQ & $\hat{\mathrm{Y}}=-1,5578+0,5942 * \mathrm{PCVZ}$ & $0,98^{* *}$ \\
HCW & $\hat{\mathrm{Y}}=-1,5578+0,5942 * \mathrm{EBW}$ & $0,98^{* *}$ \\
PCARF & $\hat{\mathrm{Y}}=-5,0373+0,5956^{*} \mathrm{PCVZ}$ & $0,97^{* *}$ \\
CCW & $\hat{\mathrm{Y}}=-5,0373+0,5956^{*} \mathrm{EBW}$ & $0,97^{* *}$ \\
\hline
\end{tabular}

** significativo a $1 \%$ de probabilidade.

** significant at $1 \%$ of probability. 


\section{Conclusões}

Com base no ganho de peso, no ganho de carcaça, na conversão alimentar e no rendimento de carcaça e de seus cortes básicos, pode-se concluir que bezerros holandeses ou mestiços 7/8 e 15/16 Holandês x Zebu, alimentados basicamente com volumosos durante a fase de cria, apresentaram bom potencial para produção de carne, em confinamento.

Foram obtidas equações de regressão linear com boas estimativas do peso corporal vazio dos novilhos de origem leiteira, em função do peso vivo e do peso da carcaça, em função do peso corporal vazio.

\section{Referências Bibliográficas}

AGRICULTURAL RESEARCH COUNCIL - ARC. 1980. The nutrient requirements of ruminants livestock. London: Commonwealth Agricultural Bureaux. 351p.

ALLEONI, G. F., BOIN, C., TROVO, J.B.F. et al. Efeito da raça de bovinos na ingestão, ganho de peso, rendimento de carcaça e digestibilidade de alimentos. In: REUNIÃO ANUAL DA SOCIEDADE BRASILEIRA DE ZOOTECNIA, 18, 1981, Goiânia. Anais... Goiânia: SBZ. 1981, p. 376.

ARANOVICH, J.F., BOIN, C., TROVO, J.B.F., et al. Engorda em confinamento de novilhos de diferentes classes e tipos alimentados com cama aviária. In: REUNIÃO ANUAL DA SOCIEDADE BRASILEIRA DE ZOOTECNIA, 18, 1981, Goiânia. Anais... Goiânia: SBZ. 1981. p. 375.

BARBER, K.A., WILSON, L.L., ZIEGLER, J.H. et al. 1981. Charolais and Angus steers slaughtered at equal percentages o mature cow weight. 1. Effects of slaughter weight and diet energy density on carcass traits. J. Anim. Sci., 52(2):218-31.

BERG, R.T., BUTTERFIELD, R.M. New concepts of cattle growth. New York: Sydney University, 1976. 240p.

BIONDI, P., SCOTT, W.N., FREITAS, E.A.N. et al. 1984. Criação e produção de bovinos machos de raças leiteiras para o corte. Zootecnia, 22(4):281-96.

CASTILLO ESTRADA, L.H. Composição corporal e exigências de proteina, energia e macroelementos minerais (Ca, $P$, $\mathrm{Mg}$, Na e K), características da carcaça e desempenho do nelore e mestiços em confinamento. Viçosa, UFV, 1996. 129p. Tese (Doutorado em Zootecnia) - Universidade Federal de Viçosa, 1996.

COMMONWEALTH SCIENTIFIC AND INDUSTRIAL RESEARCH ORGANIZATION - CSIRO. 1990. Feeding standards for Australian livestock - ruminants. Victoria: Australia Agricultural Council. 266p.

FONTES, C. A. A. Composição corporal, exigências líquidas de nutrientes para ganho de peso e desempenho produtivo de animais zebuínos e mestiços europeu-zebu. Resultados experimentais. In: SIMPÓSIO INTERNACIONAL SOBRE EXIGÊNCIAS NUTRICIONAIS DE RUMINANTES, 1995, Viçosa, MG. Anais... Viçosa, MG: JARD, 1995, p. 419-55.

GALVÃO, J.G., FONTES, C.A.A., PIRES, C.C. et al. 1991. Características e composição da carcaça de bovinos não castrados, abatidos em três estágios de maturidade de três grupos raciais. R. Soc. Bras. Zootec., 20(5):502-12.

HOGG, B.W. 1991. Compensatory growth in ruminants. In: PEARSON, A. M., DUTSUN, T. R. Growth regulation in farm animals - Advance in meat science research. London: Elsevier Applied Science, v.7, p.105.

HOOVEN JR., N.W., BOND, J., WARWICK, E.J. et al. 1972. Influence of breed and place of nutrition on the performance of dairy, dual-purpose and beef steers. 1. Birth to 180 days of age. J. Anim. Sci., 34(6):1037-45.

JORGE, A.M. Desempenho produtivo, características de carcaça e composição corporal e da carcaça de zebuínos nãocastrados, de quatro raças, abatidos em diferentes estágios de maturidade. Viçosa: UFV, 1997. 96p. Tese (Doutorado em Zootecnia) - Universidade Federal de Viçosa, 1997.

JORGE, A.M. Ganho de peso, conversão alimentar e características da carcaça de bovinos e bubalinos. Viçosa: UFV, 1993. 97p. Dissertação (Mestrado em Zootecnia) - Universidade Federal de Viçosa, 1993.

LANA, R.P., FONTES, C.A.A., PERON, A.J. et al. 1992. Conteúdo do trato gastrintestinal (digesta) e sua relação com o peso corporal e ganho de peso, em novilhos de cinco grupos raciais e bovinos machos inteiros. R. Soc. Bras. Zootec., 21(3): 510-517.

LORENZONI, W. R., CAMPOS, J., GARCIA, J. A. et al. 1986. Ganho de peso, eficiência alimentar e qualidade da carcaça de novilho búfalos, nelores, holandeses e mestiços holandêszebu. R. Soc. Bras. Zootec., 15(6):486-97.

LUCCI, C.S. 1989. Bovinos leiteiros jovens: nutrição, manejo, doenças. São Paulo: Nobel. 371p.

MARQUAT, W.R. 1964. Dairy beef in packing industry. $J$. Dairy Sci., 47(10):1145-9.

MATTOS, J.C.A., PACOLA, L.J., DRUDI, A. et al. 1977. Estudo da carcaça de novilhos Nelore. Bol. Ind. Anim., 34(2):209-16.

MATTOS, J.C.A., PEREIRA, W.M., BARBOSA, C. et al. 1974. Avaliação do desempenho e qualidade das carcaças de garrotes mestiços, recriados em pasto e confinamento, com ração baseada em excremento de aves e resíduo da debulha de milho. Bol. Ind. Anim., 31(2):173-84.

MOLETTA, J.L., RESTLE, J. 1992. Desempenho em confinamento de novilhos de diferentes grupos genéticos. $C$. Rural, 22(2):227-33.

MOLETTA, J.L., RESTLE, J. 1996. Características de carcaça de novilhos de diferentes grupos genéticos terminados em confinamento. R. Soc. Bras. Zootec., 25(5):876-88.

MORAIS, C.A.C., FONTES, C.A.A., LANA, R.P. et al. 1993. Influência da monensina sobre o ganho de peso, consumo e conversão alimentar em bovinos castrados e não-castrados. R. Soc. Bras. Zootec., 22(6):65-71.

NATIONAL RESEARCH COUNCIL - NRC. 1984. Nutrient requirements of beef cattle. 6. ed. Washington, D.C. 90p.

PATTERSON, D.C., MOORE, C.A., STEEN, R.W.J. 1994. The effects of plane of nutrition and slaughter weight on the performance and carcass composition of continental beef bulls given high forage diets. Anim. Prod., 58(1):41-7.

PATTERSON, D.C., MOORE, C.A., STEEN, R.W.J. 1995. Growth and development in beef cattle. 1. Direct and residual effects of plane of nutrition during early life on components of gain and food efficiency. J. Agric. Sci., 124(1):91-100.

PAULINO, M.F. Composição corporal e exigências de energia, proteína e macroelementos minerais ( $\mathrm{Ca}, \mathrm{P}, \mathrm{Mg}, \mathrm{Na}$ e $\mathrm{K}$ ) de bovinos não-castrados de quatro raças zebuinas, em confinamento. Viçosa: UFV, 1996. 80 p. Tese (Doutorado em Zootecnia), Universidade Federal de Viçosa, 1996.

PERON, A.J., FONTES, C.A.A., LANA, R.P. et al. 1995. Medidas quantitativas e proporções de músculos, tecido adiposo e ossos da carcaça de novilhos de cinco grupos genéticos, submetidos à alimentação restrita e "ad libitum". R. Soc. Bras. Zootec., 24(1):126-37. 
158 Rev. bras. zootec.

PERON, A.J., FONTES, C.A.A., LANA, R.P. et al. Rendimento de carcaça e de seus cortes básicos e área corporal de bovinos de cinco grupos genéticos, submetidos a alimentação restrita e "ad libitum”. R. Soc. Bras. Zootec., 22(2):238-47, 1993.

PERRY, T.C., FOX, D.G. Growth, feed efficiency, carcass composition and carcass characteristics of holstein vs beef breed steers. In: CORNELL NUTRITION CONFERENCE FOR FEED MANUFACTURES, 1992, Rochester. Proceedings ... Ithaca: Cornell University, 1992. p. 13-5.

PRESTON, T.R., WILLIS, M.B. Intensive beef production. 2. ed. Oxford: Pergamon Press, 1974. 546p.

RESTLE, J., GRASSI, C., FEIJÓ, G.L.D. Características das carcaças e da carne de bovinos inteiros ou submetidos a duas formas de castração, em condições de pastagem. R. Soc. Bras. Zootec., 25(2):334-44, 1996.

RIBEIRO, T.R. Desempenho e qualidade da carcaça de bezerros Holandeses alimentados com dietas contendo diferentes niveis de concentrado. Viçosa, MG: UFV, 1997. 101p. Dissertação (Mestrado em Zootecnia)-Universidade Federal de Viçosa, 1997.

RYAN, W.J. Compensatory growth in cattle and sheep. Nut. Abst. Rev., 60(9):653-64, 1990.
STEEL, R.G.D. TORRIE, J.H.Principles and procedures of statistics. New York: Mc Graw-Hill, Book Company, 1960. 481 p.

VELLOSO, L., SILVA, L.R.M., BOIN, C. et al. Desenvolvimento de bovinos mestiços Holandeses inteiros e castrados, em regime de confinamento e as características das carcaças. Bol. Ind. Anim., 32(1):37-45, 1975.

WESTON, R. Animal factors affeting feed intake. In: NUTRITIONAL LIMITS TO ANIMAL PRODUCTION FROM PASTURES, 1982, Sta. Lucia. Proceedings... Sta. Lucia: Queens, 1982. p. 183-98.

Recebido em: 25/06/97

Aceito em: 27/08/98 